\title{
Wildlife in Mauritius today
}

\author{
Stanley A. Temple
}

The dodo which once inhabited Mauritius has become the very symbol of extinction by man. Today, nearly $\mathbf{3 0 0}$ years after the last dodo was killed, a unique endemic fauna still survives on the island, but it is now seriously threatened; one species, the Mauritius kestrel, is believed to be down to six in the wild. The author, who has been studying Mauritian conservation problems for the past two years, describes the situation, what has been done to conserve the wildlife, and what is planned.

Mauritius is one of those small oceanic islands conservationists and naturalists have overlooked. Perhaps because of the fame of the bizarre, flightless dodo, the less spectacular endemic fauna has gone relatively neglected and unappreciated. But it survives, as unique and interesting as, for example, that of the Seychelles which has attracted so much attention.

A triangular-shaped volcanic island of about 460,800 acres in the south-west Indian Ocean, some 500 miles east of Madagascar, Mauritius has a spectacular topography with volcanic mountain peaks rising abruptly from flat plateau areas. At the end of the 16th century, when man first arrived, the island supported a truly remarkable fauna with some 40 indigenous bird species including the dodo, giant land tortoises, nearly a dozen lizard species, three snakes and two giant fruit bats. Many were quickly exterminated by man, especially the flightless birds and the tortoises. Hachisuka (1953), in his famous book, gives the most comprehensive summary of these now extinct forms, but for most little is recorded beyond their existence.

Today the surviving indigenous vertebrate fauna comprises 23 species -10 reptiles, 11 birds, and 2 mammals, most of them endangered and listed in the IUCN Red Data Book.

\section{Habitat Destruction}

Tropical vegetation covered the island when man arrived: dense evergreen forests in the lowlands and fertile uplands, with a stunted heath and scrub higher up, and palm savannas in the drier regions. Exploitation of the valuable hardwood trees quickly followed, and by the $1750 \mathrm{~s}$, most of the valuable accessible timber had been removed, and clearing for agriculture had begun in earnest. The following figures from Vaughan and Wiehe (1937) document this clearly:

$\begin{array}{cccc}\text { Date } & \begin{array}{c}\text { Estimated Native } \\ \text { Forest Acreage }\end{array} & \text { Date } & \begin{array}{c}\text { Estimated Native } \\ \text { Forest Acreage }\end{array} \\ 1753 & 406,137 & 1852 & 70,000 \\ 1770 & 388,705 & 1880 & 16,000 \\ 1804 & 313,000 & 1936 & 7,000 \\ 1836 & 300,000 & 1970 & 4,000 \\ 1846 & 142,000 & & \end{array}$



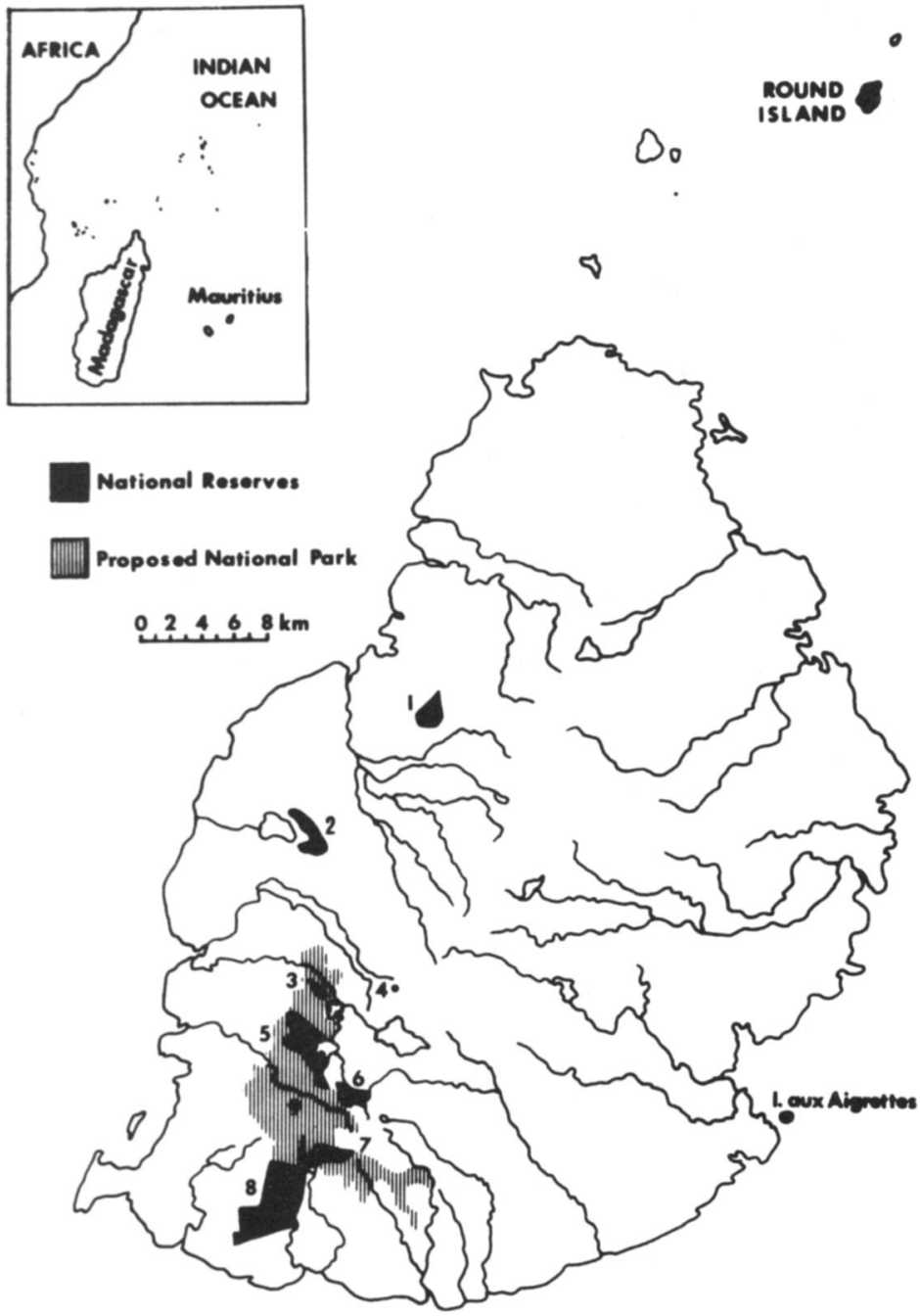

MAURITIUS. 1. Le Pouce 2. Corps de Garde 3. Cabinet 4. Perrier 5. Macabe Forest 6. Petrin. 7. Mount Cocotte 8. Bel Ombre Forest 9. Black River Gorges The effect on a fauna that evolved for life in a tropical forest is predictable.

Today nearly 60 per cent of the island is planted with sugar cane, and the human population has soared to over 875,000 , giving Mauritius one of the highest population densities in the world. The pressure on the remaining areas of native vegetation are inevitably great and increasing. In the past ten years thousands of acres have been cleared and planted with tea, pine, and eucalyptus. The foremost thought has been to develop uneconomic land. 


\section{Reptiles}

Round Island snakes Casarea dussumieri* Bolyeria multicarinata*

Telfair's skink Leiolopisma telfairii*

Bojer's skink Gongylomorphus bojerii*

Bouton's skink Ablepharus boutonii

Serpent Island gecko Cyrtodactylus serpensinsula*

Green geckos Phelsuma vinsoni

$P$. cepediana

$P$. guimbeaui

Round Island gecko $P$. guentheri*

\section{Birds}

Kestrel Falco punctatus*

Pink pigeon Columba mayeri*

Parakeet Psittacula echo*

Cave swiftlet Collocalia francica

Mascarene martin Phedina borbonica

Cuckoo-shrike Coracina typica*

Bulbul Hypsipetes olivacea*

Paradise flycatcher Terpsiphone bourbonnensis*

Olive white-eye Zosterops chloronothos*

Grey white-eye $Z$. borbonica

Fody Foudia rubra*

\section{Mammals}

Flying foxes Pteropus niger*

$P$. subniger

Very rare, declining

Very rare, possibly extinct

Localised, stable

Localised, stable

Localised, stable

Rare, declining

Common, stable

Localised, declining

Localised, declining

Rare, declining

Very rare, declining

Very rare, declining

Very rare, declining

Common, declíning

Common, stable

Very rare, declining

Localised, declining

Localised, declining

Very rare, declining

Common, stable

Very rare, declining

Rare, declining

Probably extinct

* Rare and endangered in the IUCN Red Data Book.

\section{Introductions}

Introduced predatory mammals and other exotics have brought additional problems for the indigenous fauna. The nest-robbing habits of the destructive macaque monkeys Macaca irus, from Malaysia, are a serious threat to the endemic birds. Mongooses Herpestes griseus, rats, and domestic cats are a serious threat to the endemic wildlife that had no experience of ground predators, and introduced birds compete with local species for food and nest sites.

Localised vegetation destruction by introduced mammals is also a problem. Round Island, a small 374-acre offshore islet, is the home of five lizards, two snakes, and several plants found nowhere else in the world. Rabbits and goats were released about 1850 and have so completely destroyed the natural palm thicket vegetation that there is now severe erosion. This habitat alteration threatens to eliminate a unique and one of the most scientifically interesting reptilian faunas in the world (Temple, 1974).

The Survivors

Nearly all the island's surviving species have steadily declined. Two birds and one fruit bat became extinct in the 1800 s. Since 1900 only 
The pigeon is down to about 30 individuals, and the parrot to about 50 , and the recent downward trend for both is ominous.

Several passerine bird populations have also declined markedly in recent years. The olive white-eye Zosterops chloronothos and the fody Foudia rubra depend on the same indigenous upland scrub and heath habitats, and both are now seriously threatened following the recent destruction of over 2000 acres of this type of vegetation. More destruction of this restricted habitat type is planned, and could well eliminate both species.

The endemic fruit bat or flying fox Pteropus niger, which is becoming increasingly rare and restricted in range, is greatly persecuted because of its unfortunate fondness for cultivated fruits. $P$. subniger has not been recorded in nearly 100 years and is, no doubt, extinct.

\section{Conservation Measures Taken}

The Mauritius government has taken some measures to protect its indigenous flora and fauna, although the situation is far from ideal. Since 1922 several specific laws have been enacted forbidding the shooting or capturing of the endemic birds. Unfortunately, there is little means of enforcing the law, and some shooting of endemic birds still occurs. It is believed that hunters have shot at least four kestrels and probably as many pink pigeons since 1970. A law enacted in 1973 to protect the endemic reptiles forbids the capture or killing of all endemic species, and was particularly timely in specifically forbidding their export from the island. Several foreign animal dealers had expressed considerable interest in the export of the beautiful green Phelsuma geckos.

From the point of view of preserving the endemic wildlife, the most important existing legislation is that protecting the island's remaining native vegetation. Two official forms of land classification have the effect of preserving wildlife habitat, although neither is specifically intended for that purpose.

First and most important are the lands classified as National Reserves. These are set aside at the recommendation of a nongovernmental board for their recognised value to the general public for historic or aesthetic reasons, and Mauritian conservationists have used this classification to protect some of the most important areas of natural history value-see the map. Nearly 5000 acres of governmentowned land presently falls under the national reserve system, including Round Island and some excellent areas of native forest. Unfortunately, the legislation does little more than declare the existence of these national reserves; few specific types of protection or management are prescribed. Under the second classification an additional 15,000 acres of privately-owned lands on steep mountain slopes and river banks are included in the Mountain and River Reserve system, which is mainly intended to protect watersheds, and a small portion of this land is important wildlife habitat.

Whatever the intent of these land classifications, they do at least provide token protection for some important wildlife habitats. But they leave some of the most crucial areas completely unprotected. 


\section{Future Conservation Measures}

Since 1970, a small but persistent group of Mauritian naturalists has aroused considerable interest in the island's nature conservation problems with the result that a number of important projects either are in progress or have been proposed to the government. In 1971, the government set out on a Four Year Plan for Economic and Social Development, which included a provision for the creation of a national park and nature reserve system that would preserve and protect the island's most important natural areas. The plan was to enlarge and connect the existing national reserves in the south-west to create a single park, totalling some 18,000 contiguous acres (see the map), which would include essentially all the remaining indigenous vegetation types and protect suitable habitats for all the endemic animals. A strong point in favour of the plan is that FAO experts have judged all this land to be unsuitable for agriculture because of the steep terrain and poor soil. The plans fo: this park have not yet been implemented, but they are still under consideration.

In 1973, Sir Peter Scott was invited to Mauritius to advise on local conservation problems. Foremost among the important recommendations in his report to the government (Scott 1973) was the need for properly managed national parks and nature reserves to protect remnant habitats.

Since early 1973 my wife and I have been studying the endemic wildlife, particularly the Mauritius kestrel, the pink pigeon and the parakeet. The prospects of these three surviving in the wild are doubtful, so immediate programmes of captive propagation were initiated (see Oryx, October, 1973, page 162). The plan is to breed these birds in aviaries, with the ultimate goal of reintroducing progeny into the wild in secure areas. This may be the last hope for these three species.

This year the British Ornithologists' Union mounted a small expedition to the Mascarene Islands, which includes Mauritius, and they will devote part of their time to the study of the endangered passerine species of Mauritius with a view to determining how best to preserve them.

During 1974 a poisoning programme is planned to eliminate the introduced rabbits and goats on Round Island. Once these pests have been exterminated the forestry department has plans for erosion control and reafforestation.

Certainly the task of preserving the endemic fauna of Mauritius is no easy one. The situation has deteriorated to such an extent that some additional forms will almost certainly become extinct. But, if the remaining indigenous vegetation can be protected and the Mauritian people made aware of the value of their natural heritage, there is hope that much of the island's unique wildlife will survive for future generations to appreciate.

\section{Acknowledgments}

My work on wildlife conservation on Mauritius was financed and sponsored by the International Council for Bird Preservation, the 
World Wildlife Fund (US Appeal), and the New York Zoological Society. The enthusiastic assistance and support given me by Mauritian naturalists and conservationists is gratefully acknowledged.

\section{References}

HACHISUKA, M. 1953. The Dodo and kindred birds. Witherby, London.

SCOTT, P. 1973. Conservation on Mauritius. Unpublished report to the Mauritius Government.

TEMPLE, S.A. 1974. Last chance to save Round Island. Wildlife 16: 370-374.

VAUGHAN, R.E. and P.O. WIEHE 1937. Studies on the vegetation of Mauritius. J. Ecol., 25: 290-343.

\section{A Hunter's Welcome for a Reserve}

A Nigerian hunter's reactions to the creation of a game reserve in his former hunting grounds are described in The Nigerian Field for June 1974. The Yankari Game Reserve was created in 1962. In 1972 some university students speaking the local language interviewed local people as part of a study of conservation problems affecting the reserve. One 50-year old hunter proved particularly informative and knowledgable. Asked 'what is the attitude of hunters to the reserve in its present form?', he replied,

'At first we were a little bit disturbed since we then felt we were being deprived of our legitimate source of income, although even then we knew without doing something the wildlife reservoir would sooner or later be depleted. But later when we saw that some of us were employed in the reserve, our children could also obtain work and the little ones had the opportunity of going to school, we began to feel happier. We also saw that many people, particularly foreigners, took a keen interest in visiting the reserve, and in fact some of us are now saying "Why did this exercise not start earlier?",

Asked for his overall impression of the reserve, he said,

'There is every indication that game are continually attracted to this reserve because of the tranquillity that prevails. Wildlife could have been depleted by now if the reserve had not been established, and since that time, especially in these recent years, the reserve has shown a marked improvement. I believe that with proper and effective management it will provide an attraction for many people, and will even be comparable to the other places we have been hearing of. In fact we all praise the Government and the individuals involved in the development of Yankari Game Reserve for their foresight, continued efforts and interest'.

What the writer of the article does not say is whether this man's views were typical among the people interviewed, or whether he was exceptional.

\section{Over 50 years a Member}

Mr E.P. Field, who now lives in Australia, has been a member of the FPS since 1922. He wrote to ask if his is now the longest membership. The answer is, not quite-for Mr Geoffrey Dent, of Yorkshire, was elected in 1919. Mr. Dent was Hon. Treasurer 1920-50 and a Council member until 1958. 